\title{
Who Writes the Biggest Check for Charitable Care: A Comparison of For-Profit, Not-for-Profit, and Government Hospitals
}

\author{
John G. Irwin ${ }^{1}$, Carmen C. Lewis ${ }^{1}$, Cherie Fretwell ${ }^{1} \&$ Randi E. Myers ${ }^{1}$ \\ ${ }^{1}$ Sorrell College of Business, Troy University, Phenix City, Alabama, USA \\ Correspondence: Carmen Lewis, Sorrell College of Business, Troy University, Phenix City, AL., US. Tel: \\ 1-334-448-5168. E-mail: cclewis@troy.edu
}

Received: December 10, 2014

Accepted: January 8, 2015

Online Published: January 14, 2015

doi:10.5430/afr.v4n1p151

URL: http://dx.doi.org/10.5430/afr.v4n1p151

\begin{abstract}
The current environment in the United States surrounding health care issues such as spending, costs, access, and affordability points toward a societal obligation to help provide for those who cannot pay the costs of their own care. Hospitals are often one of the largest employers in communities, and like many other organizations, view providing charitable care as an aspect of their corporate social responsibility (CSR). This study compares the recent levels of charitable care of for-profit, not-for-profit, and government hospitals. The authors attempt to determine which type of hospital is the most charitable, what the relationship between CSR and profitability may be, and the differences in the relationship between CSR and profitability for various hospital types. Data from a sample of 167 short-term, general hospitals were examined and results indicated that there were significant differences in CSR for government, not-for-profit and for-profit. Higher levels of CSR did not affect firm profitability, although significant interactions were found between control and CSR for varying levels of profitability.
\end{abstract}

Keywords: Corporate social responsibility, Stakeholder theory, Hospital profitability

\section{Introduction}

Health care spending is a number greater now than most people can comprehend. According to a feature article in Forbes, patients are spending $\$ 3.46$ trillion a year with a $4 \%$ growth projected each year. Over the last two years, consumer out-of-pocket spending increased by about $\$ 52$ billion (Munro, 2014). In spite of reports that spending costs have slowed in recent years and that reform may decrease costs, "health care spending remains one of the greatest threats to our national security and prosperity" (Lynch, 2013). Another distressing comparison shows that "health care spending has increased eleven times faster than education spending over the last 50 years, and we now spend 33\% more on health care than education" (Lynch, 2013).

The proportion of uninsured Americans is also dramatically shifting. That is, the estimated number of people in the U.S. without health insurance is over 43 million, a number that has increased by over a million in each of the last three years. In addition to the growing number of uninsured, about 29 million people are underinsured, meaning this group with private insurance are at risk of financial disaster in the case of serious illness or injury. The number of underinsured Americans has increased by nearly 50\% over the last decade. These changes are also being reflected in hospitals' total cost of uncompensated care ("The New Health Care Delivery System - A Guide for Nurses," 2014). Rising deductibles shifts the risk from insurers to individuals, thereby increasing the chances that hospitals will not receive payment for services. "Hospitals' total cost of uncompensated care reached $\$ 46$ billion in 2012, equal to about 6 percent of their expenses" (Tozzi, 2014).

The healthcare industry also faces a variety of operational challenges such as stringent regulatory compliance, intense labor shortages in nursing, increased and costly technological advancements, and implementation of international quality standards, along with substantial community dependence. Access to health care often dominates discussions of social responsibility, as health care typically represents the largest portion of society's resources (Resnik, 2007). Still, responsibility for health is often viewed as a "... collaborative effort among individuals and the societies in which they live" (Resnik, 2007). That is, along with individual responsibility for their health and the costs of their own healthcare, it is typically thought that "societies should promote health and help to finance the costs of healthcare" (Resnik, 2007). 
In essence, the healthcare industry is in a period of dramatic change. With the growing number of uninsured and underinsured individuals, along with rising deductibles, hospitals have experienced lower levels of profitability. However, society expectation maintains that hospitals demonstrate high levels of social responsibility in funding the growing costs of healthcare. In an effort to assimilate these opposing forces, this paper compares the recent levels of charitable care of for-profit, not-for-profit, and government hospitals. Therefore, we address the following research questions:

RQ: Which type of hospital is the most charitable? What is the relationship between social responsibility and profitability?

The rest of this paper is presented as follows: First, a review of relevant literature regarding corporate social responsibility and stakeholder theory is presented and a set of hypotheses is developed. Next the methodology and sample selection is described, followed by the results of our analyses. The paper concludes with a summary of expected contributions, limitations, and opportunities for future research.

\section{Literature Review and Hypotheses Development}

\subsection{Corporate Social Responsibility}

Historically, academicians and business executives have spoken of social responsibility, or, more often what is heard currently, corporate social responsibility (CSR). Although Wendell Wilkie referred to "social responsibility" in the 1930s (Cheit, 1964), major publicity about the concept began with the 1953 landmark book, Social Responsibilities of the Businessman (Bowen \& Johnson, 1953). As the concept began to generate wide-spread discussions of the social responsibilities of businesses, however, a lack of consensus as to meaning of the concept contributed to ambiguous interpretations (Carroll, 1979). In 1960, the definition put forth was that social responsibility refers to "businessmen's decisions and actions taken for reasons at least partially beyond the firm's direct economic or technical interest" (Davis).

The development of an institutional theory of the determinants of CSR wherein conditions are specified "under which corporations are likely to behave in socially responsible ways" suggests a relationship between basic economic conditions and corporate behavior, and further that the relationship is impacted by various institutional conditions (Donaldson \& Preston, 1995). Another important contribution from this research is the "threshold between socially responsible and irresponsible behavior" (1995). The author actually speculates that the idea of businesses acting in socially responsible ways may seem silly to some people. He contends that if the goals of corporations are to maximize profit and shareholder value, "then it stands to reason that corporations will do whatever it takes to achieve this goal-perhaps even if that includes acting in socially irresponsible ways if they believe that they can get away with it" (1995) .

Although many conceptualizations exist for CSR, the idea that all organizations should be concerned beyond making a profit by engaging in "actions that appear to further some social good, beyond the interests of the firm and that which is required by law" (McWilliams, Siegel, \& Wright, 2006) appears to be a common denominator. CSR has moved from more "voluntary practices to more explicit commitments in response to stakeholder pressures and ongoing commitments" (Winn, MacDonald, \& Zietsma, 2008). Currently, CSR more likely refers to business decision making related to ethical values, compliance with legal requirements, and respect for people, communities and the environment (Carroll, 1979; Maignan, Ferrell, \& Hult, 1999). This advances the concept of stakeholders as central to CSR and further refines the definition of CSR as "the extent to which businesses assume the economic, legal, ethical and discretionary responsibilities imposed on them by their various stakeholders" (Carroll, 1979; Maignan et al., 1999).

Contrasting views with regard to the relationship between an organization's financial performance and its emphasis on social responsibility include the following. The first of these views is that organizations "face a trade-off between social responsibility and financial performance" (Frooman, 1999). Those who hold this view believe that "firms incur costs from socially responsible actions that put them at an economic disadvantage compared to other, less responsible, firms" (Hill \& Jones, 1992). A second view is that the "explicit costs of corporate social responsibility are minimal and that firms may actually benefit from socially responsible actions in terms of employee morale and productivity" (Solomon, 1985). The third view is that the "costs of socially responsible actions are significant but are offset by a reduction in other firm costs" (Frooman, 1999).

An attempt to utilize the supply and demand theory of the firm to determine how much a firm should spend on CSR resulted in findings that suggest "there is a level of CSR investment that maximizes profit, while also satisfying stakeholder demand for CSR" (McWilliams \& Siegel, 2001). These authors posit that this ideal level can be 
determined with a cost-benefit analysis, and that "although firms providing CSR will have higher costs than firms not providing CSR, they will each have the same rate of profit" (2001).

Efforts to establish a business case for promoting CSR focused on this basic question: "What do the business community and organizations get out of CSR?" (Carroll \& Shabana, 2010). In other words, what are the tangible benefits from embracing CSR activities and practices? Their rationale for the business case is based on four distinct arguments. The first two involve reducing cost and risk and strengthening legitimacy and reputation. The reduction of cost and risk may allow a firm to realize tax benefits, which would lower its cost. If firms can meet the needs of their stakeholders and at the same time operate at a profit, opposition to CSR activities by stakeholders could potentially be minimized and a firm's legitimacy and reputation may be strengthened. A third argument is building competitive advantage, which if a firm adopts certain CSR activities they may be able to "build strong support in the form of lower levels of employee turnover, access to a higher talent pool, and customer loyalty" (2010), all of which should differentiate the firm from its competitors. A final argument is synergistic value creation, which suggests that CSR activities may "present opportunities for a firm that would allow it to fulfill the needs of its stakeholders and at the same time pursue its profit goals" (2010). The authors contend that these opportunities would only be possible through CSR activities.

\subsection{Stakeholder Theory}

Stakeholder management, in its initial conceptualization, was posited by Freeman (1984), who developed the preliminary concepts in a book entitled Strategic Management: A Stakeholder Approach. Donaldson and Preston later extended Freeman's research by establishing four central theses: The stakeholder theory is (1) descriptive, (2) instrumental, (3) fundamentally normative, and (4) managerial (1995). That is, the model (see Figure 1) describes what the corporation is, and can be utilized as a framework to test empirical assertions such as the suggested instrumental relationship between stakeholder management and firm performance. Furthermore, its normative quality implies an acceptance of stakeholders being identified by their "... legitimate interests in procedural and/or substantive aspects of corporate activity" and consideration for their own sake. In other words, stakeholders' interests are of intrinsic value in that they participate in the firm's activities to obtain benefits. Finally, the broadly construed managerial quality requires simultaneous attention to the interests of all stakeholders "...both in the establishment of organizational structures and general policies and in case-by-case decision making" (Donaldson \& Preston, 1995, p. $67)$.

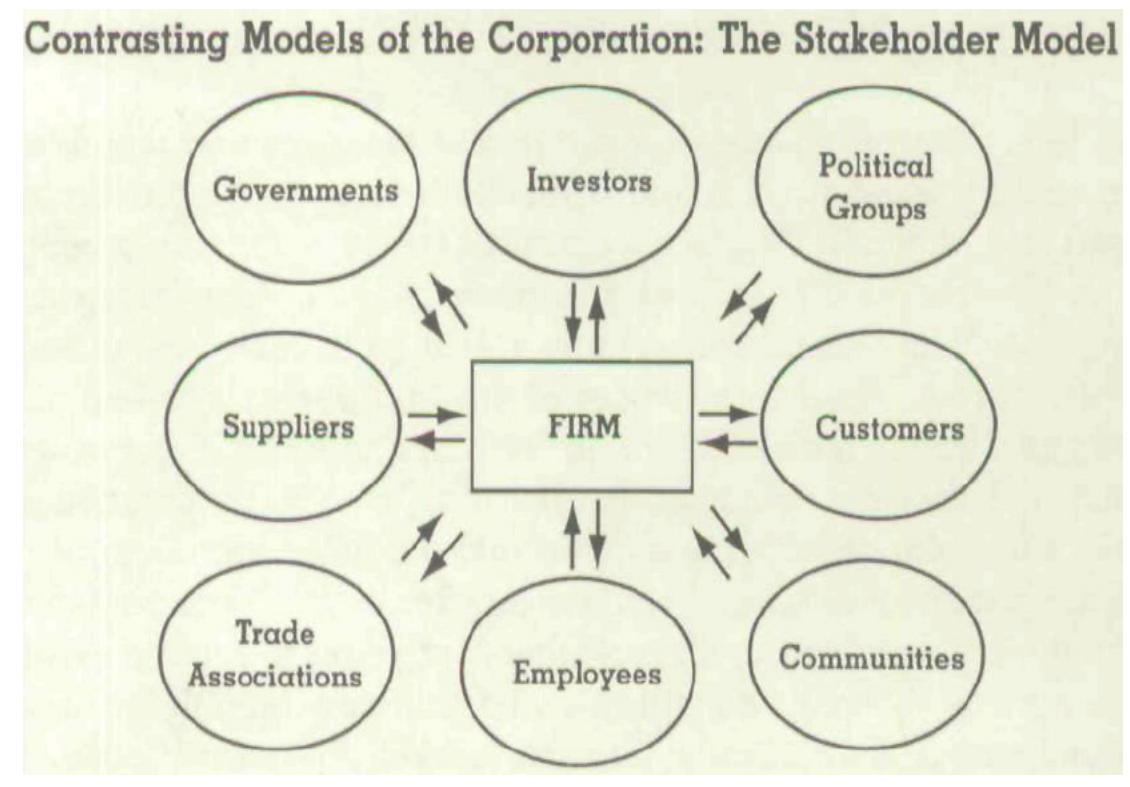

Figure 1. The Stakeholder Model (Donaldson \& Preston, 1995)

In addition to formally introducing stakeholder management as a theory, Donaldson and Preston (1995) also differentiated its tenets pertaining to three different aspects, each having different implications: descriptive/empirical, instrumental, and normative. First, descriptive/empirical suggests the theory is used to aid in explaining organizational characteristics and behaviors, such as those of managers and board members. Second, instrumental 
suggests a relationship between stakeholder management and conventional corporate objectives, such that adherence to stakeholder principles and practices results in higher corporate performance, e.g., profitability. Finally, the normative aspect of the theory is used to identify "...moral or philosophical guidelines for the operation and management of corporations" (Donaldson \& Preston, 1995, p. 71). Thus, the theory serves as an attempt to clarify essential differences among these three competing views.

For the purposes of this paper, we apply both the normative and instrumental approaches. First, the normative aspect of stakeholder theory relates to CSR due to the expectation of firms (to a large extent) to engage in such actions because it is the "right thing to do." The second aspect, instrumental, is also an appropriate lens as it outlines the relationship between stakeholder approaches and firm performance.

\subsection{Hypotheses}

Based on the previous discussions of CSR and stakeholder theory, a for-profit business does have incentives to be socially responsible. However, the for-profit business still must have profitability as its primary objective. For-profit hospitals are expected to be profitable while still practicing CSR.

With respect to not-for-profit organizations, it is assumed that organizations of this type are organized for a purpose other than to produce returns to owners (Marsteller, Bovbjerg, \& Nichols, 1998). As a result, any revenues they produce in excess of expenditures may not be distributed but rather are used in support of the organization's mission, which will likely include the provision of charity care. This is consistent with traditional views of not-for-profit hospitals as providers of medical care for uninsured patients and patients who are otherwise unable to pay. Not-for-profit hospitals should thus exhibit higher CSR as shown by higher levels of charity care than that of for-profit hospitals.

Finally, with respect to government hospitals, there is even less incentive to break-even and generate excess revenues since revenues generated directly by patient care are supplemented by government funds. CSR as exhibited by the provision of charity care should thus be greatest for government hospitals.

For the purposes of this research project, a hospital's level of charitable care is considered to be a proxy for the hospital's corporate social responsibility. Charitable care is compared among for-profit, not-for-profit, and government hospitals and the following hypothesis is thus offered:

$H_{1}$ : The relationship between CSR and hospital control is such that the highest level of CSR is associated with governmental, followed by not-for-profit. The lowest levels of CSR are associated with for-profit organizations.

With respect to the provision of charity and profitability, the earlier discussions on CSR and stakeholder theory suggest that CSR should not affect profitability.

The hypothesis thus formulated in our study is as follows:

\section{$\mathrm{H}_{2}$ : Higher levels of CSR do not affect firm profitability overall.}

\section{Research Methodology}

\subsection{Data Collection and Methodology}

In order to test the hypotheses, an initial search was first performed of hospital financial data. We used an annual publication of hospital financial data which was obtained from the state of Florida's Agency for Health Care Administration. The sample covers financial data recorded by all general, short-term hospitals in Florida for fiscal year ending 12/31/2012. By limiting the analyses to those of general care, short-term hospitals, we were able to compare those with similar characteristics. That is, long-term care, specialty and rehabilitation hospitals were excluded from the analyses. After excluding one hospital with incomplete data we were left with a total of 167 hospitals including twenty government hospitals, sixty-six not-for-profit hospitals, and seventy-eight for-profit hospitals.

While focusing on hospital financial data for one state affects the generalizability of the findings, we felt that at this early stage of development it was more important to assess differences that may be introduced across hospitals and standardize data collection. Use of a single state controls for environmental variables that vary from state to state such as regulatory stringency (Zajac \& Shortell, 1989). The unit of analysis is the 167 hospitals. The constructs were assessed through objective measures based on data that were publicly available on the Agency for Health Care Administration website (http://ahca.myflorida.com/). 


\subsection{Dependent Variables}

The dependent variable is the hospital's level of profitability. For the purpose of this research, we define profitability using three measures: 1) operating margin (OPM); 2) excess or deficit of revenues over expenses prior to taxes or extraordinary items (EBT) divided by revenue (EBT margin); and 3) net profit margin (NPM).

\subsection{Independent Variables}

Control refers to the hospital classification as either government, not-for-profit, or for-profit (coded 0 , 1 , and 2 , respectively in the ANOVA test). This classification was provided with the remaining data on the Agency for Health Care Administration website. Control served as an antecedent to corporate social responsibility. For a post-hoc analysis, it was also modeled as a moderating variable to the relationship between corporate social responsibility and hospital profitability. Corporate social responsibility refers to the amount of charity care given by a hospital in the year 2012. Charity care, as defined in subsections 409.2663(2) and 409.911(1), states...

Florida Statutes, charity care is that portion of hospital charges for which there is no compensation for care provided to a patient whose family income for the 12 months preceding the determination is less than or equal to 150 percent of the current Federal Poverty Guidelines (FPG), as published in the Federal Register; or for which there is no compensation for care provided to a patient whose family income for the 12 months preceding the determination is greater than 150 percent of the current FPG but not more than four times the current FPG for a family of four and the amount of hospital charges due from the patient exceeds 25 percent of the 12-month family income. Charity care does not include bad debt, which is the portion of health care provider charges for which there is no compensation for care provided to a patient who fails to qualify for charity care; and does not include administrative or courtesy discounts, contractual allowances to third-party payers, or failure of the hospital to collect full charges due to partial payment by government programs ("59C-1.039 Comprehensive Medical Rehabilitation Inpatient Services,").

In order to obtain a value for the analyses using the corporate social responsibility construct for a given hospital, a ratio was used (i.e., total charity care to the hospital's total revenue). The results of this ratio used in the analyses were labeled Charity.

Since organization size has been known to affect outcomes (Finkelstein, 1992), included in the analyses was a control variable for the size of the hospital. With respect to hospitals specifically, Alexander, Anderson, and Lewis (1985) found hospital size to be positively associated with profitability. While organization size has been most commonly measured by the number of employees, in hospitals the most common measure used has been the number of beds (Kimberly \& Evanisko, 1981). Therefore, in maintaining consistency with prior studies, we measured hospital size by using the number of beds in the hospital (Kimberly \& Evanisko, 1981; Meyer \& Goes, 1988). Its natural $\log$ was used to adjust for the likely diminishing effects of size at high levels, which is consistent with that of other researchers (Kimberly \& Evanisko, 1981; Meyer \& Goes, 1988).

\section{Results}

The research data were tested using ANOVA and regression analysis, using IBM SPSS Statistics Software version 21. By distinguishing the type of control used to run the hospitals and limiting the analyses to those of general care, short-term hospitals, we were able to compare those with similar characteristics. That is, long-term care and rehabilitation hospitals were excluded from the analyses. After excluding observations that did not meet the stated hospital type, 167 hospitals remained. Of the 167, twenty were government hospitals, sixty-five were not-for-profit, and eighty-two for-profit.

\subsection{Descriptive Statistics}

Full descriptive statistics for each of the 167 hospitals are provided in Table 1. The most charitable hospital contributed $\$ 321,006,592$ to charitable care. Interestingly, this amount is $\$ 139,041,549$ more than the second largest contributor. Only one hospital in the sample had no charity recorded. This for-profit hospital exhibited dismal profitability measures, with a $-3.1 \%$ operating margin and $-.7 \%$ net profit margin. The average charity to total revenue margin was $3.22 \%$ with a standard deviation of $2.63 \%$. 
Table 1. Descriptive statistics

\begin{tabular}{lrrrr}
\hline \multicolumn{1}{c}{ Mean } & \multicolumn{1}{c}{ Min } & Max & \multicolumn{1}{c}{ Std Dev } \\
\hline Hospital Beds & 323 & 15 & 9,150 & 723 \\
\# Employees & 1,049 & 50 & 5,422 & 973 \\
\% Occupied & $51.8 \%$ & $0.40 \%$ & $88.50 \%$ & $17.31 \%$ \\
Total Revenue & $\$ 876,230,013$ & $\$ 9,375,416$ & $\$ 3,552,797,742$ & $\$ 720,073,715$ \\
Total Charity & $\$ 29,538,719$ & 0 & $\$ 321,006,592$ & $\$ 41,201,222$ \\
OPM & $2.76 \%$ & $-92.40 \%$ & $31.20 \%$ & $15.46 \%$ \\
EBT & $\$ 15,794,587$ & $\$(37,380,202)$ & $\$ 189,552,768$ & $\$ 26,465,405$ \\
NPM & $4.80 \%$ & $-63.50 \%$ & $32.20 \%$ & $11.99 \%$ \\
Charity & $3.22 \%$ & $0 \%$ & $14.12 \%$ & $2.63 \%$ \\
EBT Margin $^{\text {a }}$ & $0.95 \%$ & $-21.62 \%$ & $8.75 \%$ & $3.52 \%$ \\
\hline
\end{tabular}

${ }^{\mathrm{a}}$ Charity is a percent of total revenue.

The amount of corporate social responsibility varies for each hospital control. The level of corporate social responsibility, as measured by the amount of charity to total revenue for each control can be seen in Table 2, along with other descriptives. Charity figures described below are yearly amounts for 2012. The highest mean charitable contributions are associated with government hospitals at $5.79 \%$ of total revenue or $\$ 51,421,043$, followed by not-for-profits at $4.02 \%$ or $\$ 38,009,015$. As such, the least charitable hospital control type was for-profits at $1.15 \%$ or $\$ 17,487,308$. At a mean of 695 , for-profits also employed the fewest number of employees, compared to government (1327) and not-for-profits (1410).

Table 2. Means and standard deviations for each control

\begin{tabular}{lcccccc}
\hline & \multicolumn{2}{c}{ Government } & \multicolumn{2}{c}{ Not-for-Profit } & \multicolumn{2}{c}{ For-Profit } \\
& Mean & Std Dev & Mean & Std Dev & Mean & Std Dev \\
\hline Hospital Beds & 278 & 292 & 434 & 1123 & 246 & 192 \\
\# Employees & 1327 & 1412 & 1410 & 1151 & 695 & 421 \\
\% Occupied & $43.78 \%$ & $18.16 \%$ & $53.18 \%$ & $16.14 \%$ & $52.85 \%$ & $17.67 \%$ \\
Total Revenue (\$) & $814,989,464$ & $928,221,708$ & $894,990,472$ & $756,673,831$ & $876,295,637$ & $637,900,518$ \\
Total Charity (\$) & $51,421,043$ & $77,976,356$ & $38,009,015$ & $40,288,061$ & $17,487,308$ & $21,150,853$ \\
OPM & $-7.50 \%$ & $24.44 \%$ & $2.64 \%$ & $14.49 \%$ & $5.36 \%$ & $12.28 \%$ \\
EBT (\$) & $11,591,962$ & $21,555,530$ & $18,792,953$ & $32,528,217$ & $14,442,864$ & $21,840,130$ \\
NPM & $2.92 \%$ & $9.59 \%$ & $4.11 \%$ & $13.63 \%$ & $5.81 \%$ & $11.13 \%$ \\
Charity & $5.79 \%$ & $3.16 \%$ & $4.02 \%$ & $2.35 \%$ & $1.95 \%$ & $1.93 \%$ \\
EBT Margin & $0.71 \%$ & $2.71 \%$ & $0.77 \%$ & $4.47 \%$ & $1.15 \%$ & $2.80 \%$ \\
\hline
\end{tabular}

${ }^{\mathrm{a}}$ Charity is a percent of total revenue.

$\mathrm{n}=20$ Government; $\mathrm{n}=65$ not-for-profit, $\mathrm{n}=82$ for-profit

The correlation matrix, shown in Table 3 , displays the highest correlation with charity to be total revenue $(\mathrm{r}=.756, \mathrm{p}$ $<.01)$. Therefore, hospitals with the most revenue also contributed the most to charity. Charity was also significantly correlated with percent occupancy $(\mathrm{r}=.225, \mathrm{p}<.01)$. 
Table 3. Correlations ${ }^{\mathrm{a}}$

\begin{tabular}{|c|c|c|c|c|c|c|c|c|}
\hline & 1 & 2 & 3 & 4 & 5 & 6 & 7 & 8 \\
\hline $\begin{array}{l}\text { 1. Percent } \\
\text { Occupancy }\end{array}$ & 1 & & & & & & & \\
\hline 2. Total Revenue & $.422 * *$ & 1 & & & & & & \\
\hline 3. Total Charity & $.225 * *$ & $.756 * *$ & 1 & & & & & \\
\hline 4. OPM & $.373 * *$ & $.334 * *$ & .124 & 1 & & & & \\
\hline 5. NPM & $.347 * *$ & $.333 * *$ & $.153 *$ & $.843 * *$ & 1 & & & \\
\hline 6. EBT & $.353 * *$ & $.680 * *$ & $.469 * *$ & $.467 * *$ & $.576^{* *}$ & 1 & & \\
\hline $\begin{array}{l}\text { 7. Charity } \% \text { of } \\
\text { Revenue }\end{array}$ & -.099 & .072 & $.497 * *$ & -.137 & -.002 & .015 & 1 & \\
\hline 8. EBT Margin & $.308 * *$ & $.297 * *$ & $.165^{*}$ & $.784 * *$ & $.944 * *$ & $.480 * *$ & .074 & 1 \\
\hline
\end{tabular}

${ }^{\mathrm{a}} \mathrm{N}=167$

$* \mathrm{p}<.05$, two-tailed test

$* * \mathrm{p}<.01$, two-tailed test

4.2 Results of the Analysis of Variance Test

To determine if there were significant differences in levels of corporate social responsibility (CSR) between government, not-for-profit, and for-profit hospitals, a one-way analysis of variance (ANOVA) test was run. The F-test for between group differences was significant $(F=29.55, p<0.01)$. See Table 4 for complete ANOVA results. Post hoc comparisons were also used to identify which groups differed in their levels of CSR. The Tukey HSD procedure is recommended for one-way ANOVA when the family of tests consists of all possible pairwise comparisons of the means (Tate, 1998). Results indicated significant differences between all three groups. That is, Table 5 displays government hospitals' CSR levels significantly exceeded both not-for-profits $(p<.01)$ and for-profits $(p<.01)$. Furthermore, not-for-profits' CSR levels significantly exceeded for-profits $(p<.01)$. Thus, hypothesis 1 was supported.

Table 4. ANOVA results for differences in CSR between controls

\begin{tabular}{|c|c|c|c|c|c|}
\hline & Sum of Squares & df & Mean Square & $\mathrm{F}$ & Sig. \\
\hline Between Groups & 304.400 & 2 & 152.200 & 29.550 & $.000 * *$ \\
\hline Within Groups & 844.706 & 164 & 5.151 & & \\
\hline Total & 1149.105 & 166 & & & \\
\hline
\end{tabular}

a $\mathrm{N}=167$

$* * \mathrm{p}<.01$, two-tailed test.

Table 5. Tukey HSD procedure for simultaneous inference

\begin{tabular}{llcrrrr}
\hline (I) Control & (J) Control & $\begin{array}{c}\text { Mean Difference } \\
\text { (I-J) }\end{array}$ & Std. Error & Sig. & \multicolumn{2}{c}{$95 \%$ Confidence Interval } \\
& & & & & Lower Bound & Upper Bound \\
\hline \multirow{2}{*}{ Government } & Not-For-Profit & $1.76935^{* *}$ & .58032 & .008 & .3968 & 3.1419 \\
& For-Profit & $3.83218^{* *}$ & .56599 & .000 & 2.4935 & 5.1709 \\
\multirow{2}{*}{ Not-For-Profit } & Government & $-1.76935^{* *}$ & .58032 & .008 & -3.1419 & -.3968 \\
& For-Profit & $2.06283^{* *}$ & .37690 & .000 & 1.1714 & 2.9543 \\
\multirow{2}{*}{ For-Profit } & Government & $-3.83218^{* *}$ & .56599 & .000 & -5.1709 & -2.4935 \\
& Not-For-Profit & $-2.06283^{* *}$ & .37690 & .000 & -2.9543 & -1.1714 \\
\hline
\end{tabular}

$\mathrm{N}=167$

$* \mathrm{p}<.05$, two-tailed test

$* * \mathrm{p}<.01$, two-tailed test 


\subsection{Results of the Stepwise Regression Model}

In order to understand how corporate social responsibility impacts hospital profitability, we used stepwise regression analysis to examine its significance. To control for hospital size, we used a log transformation and entered it in the first block. CSR was entered in the second block to examine its impact above and beyond the control variable. This process was conducted for each of the three dependent measures.

Findings showed the control variable, number of hospital beds, to significantly predict OPM, EBT margin, and NPM. Adding the number of beds as a predictor in the OPM model resulting in an $\mathrm{R}^{2}$ of $7.5 \%$. As for hypothesis 2 , which stated that higher levels of CSR would not affect firm profitability, we also found support. The level of CSR did not result in changes in either OPM, EBT margin, or NPM.

\subsubsection{Additional Analysis: Test for Interaction with Operating Margin as the Dependent Variable}

Post hoc tests were also conducted to determine if organization control would moderate the relationship between CSR and profitability. That is, in comparing organization control for the three types, government, not-for-profit, and for-profit, we tested for the existence of an interaction effect between it and CSR. Specifically, we wanted to determine if profitability differences among the three controls would vary across levels of CSR. Therefore, hospital controls, along with their interactions with CSR were entered into the third block of the stepwise regression model. The interaction terms were defined as the products of CSR (measured by mean-centered charity to total revenue) and hospital control (coded).

Model 1: OPM $=\beta_{0}+\beta_{1} X_{1}$

Model 2: OPM $=\beta_{0}+\beta_{1} X_{1}+\beta_{1} X_{1}$

Model 3: OPM $=\beta_{0}+\beta_{1} X_{1}+\beta_{2} X_{2}+\beta_{3} X_{3}+\beta_{4} X_{4}+\beta_{5} X_{2} X_{3}+\beta_{6} X_{2} X_{4}$

Hospital Beds $\quad \mathrm{X}_{1}$

Charity Margin $\quad \mathrm{X}_{2}$

First group, aka Control (not-for-profit): $\mathrm{X}_{3}=1, \mathrm{X}_{4}=0$

Second group, aka Control_2 (for-profit): $\mathrm{X}_{3}=0, \mathrm{X}_{4}=1$

Third group (government): $\quad \mathrm{X}_{3}=0, \mathrm{X}_{4}=0$

$\mathrm{OPM}=$ Operating Profit Margin: $\quad$ Dependent variable

Partial support was found, such that the interaction between control and charity was not significant in predicting profitability for each of the three measures; however, the interaction between control_2 and charity had a significant effect on OPM. The coefficient for control_2 shows the effects of for-profit hospitals. Since we centered the charity variable, the coefficient shows the effect of for-profits at the mean CSR level of 0 . Therefore, OPM was reduced by 1.78 units at the mean CSR level in for-profit hospitals. However, the improvement in $\mathrm{R}^{2}$ was only $3 \%$, so although the effect of the interaction was significant, it had little practical importance. The results of the analysis are presented in Table 6.

Table 6. Beta coefficients from stepwise regression analysis for operating margin as the dependent variable

\begin{tabular}{|c|c|c|c|c|c|c|c|c|c|}
\hline \multirow{2}{*}{ Variables } & \multicolumn{9}{|c|}{ Dependent Variable: Operating Margin (OPM) } \\
\hline & \multicolumn{3}{|c|}{ Model 1} & \multicolumn{3}{|c|}{ Model 2} & \multicolumn{3}{|c|}{ Model 3} \\
\hline & Coef & $t$ & $P$-value & Coef & $t$ & P-value & Coef & $t$ & P-value \\
\hline Hospital Beds & 10.058 & 3.72 & $.000 * *$ & 10.072 & 3.75 & $.000^{* *}$ & 9.891 & 3.74 & $.000^{* *}$ \\
\hline Charity/Total Revenue & & & & -.809 & -1.85 & .065 & -.084 & -1.78 & .078 \\
\hline Control & & & & & & & -.024 & -.319 & .750 \\
\hline Control_2 & & & & & & & .110 & 1.32 & .189 \\
\hline Control $x$ Charity & & & & & & & -.031 & -.267 & .790 \\
\hline Control 2 x Charity & & & & & & & -1.775 & -2.23 & $.027 *$ \\
\hline $\mathbf{R}^{\mathbf{2}} \mathbf{a d j}$ & & $7.2 \%$ & & & $8.5 \%$ & & & $11.5 \%$ & \\
\hline $\mathbf{F}$ & & 13.829 & & & 8.736 & & & 8.201 & \\
\hline $\begin{array}{l}\mathrm{N}=167 \\
* \mathrm{p}<.05 \\
* * \mathrm{p}<.01\end{array}$ & & & & & & & & & \\
\hline
\end{tabular}


The resulting three lines from the scatterplot of the model are shown in Figure 2. The vertical distances between the lines for a given charity margin reflect the effect for hospital control, while the slope of each line represents the effect of the charity variable. The nonparallel pattern of lines resulting from the unequal slopes indicates a slight interaction effect. Operating profit margin of for-profit hospitals is lower than not-for-profits at higher charity levels. Both the not-for-profit and for-profit hospitals appear to result in higher operating profit margins than the government hospitals across the range of charity levels.

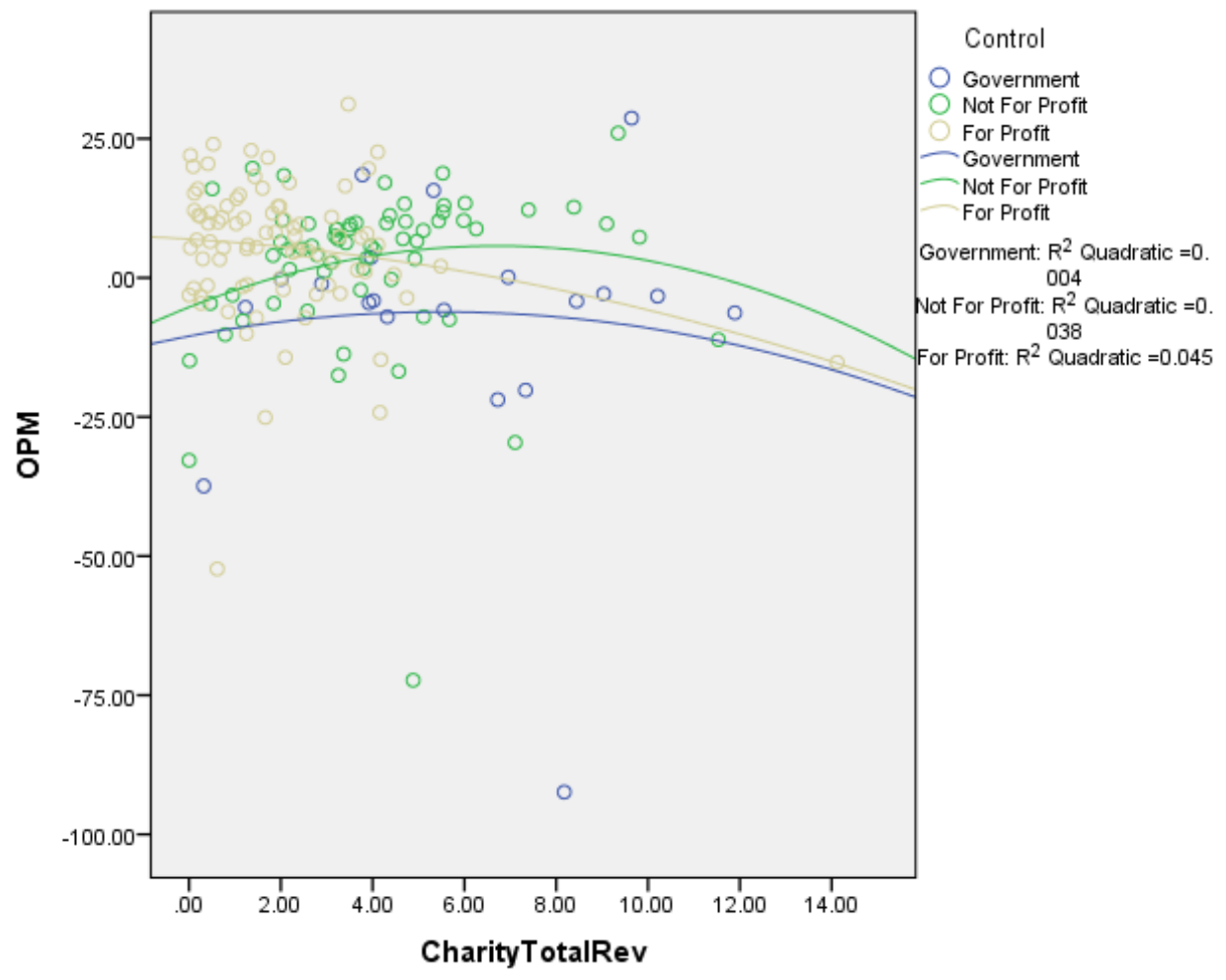

Figure 2. Scatterplot of charity margin to OPM for the three controls

4.3.2 Additional Analysis: Test for Interaction with Earnings before Taxes Margin as the Dependent Variable

Similar to the previous analysis, three models were assessed, this time with EBT margin as the dependent variable. The control variable, hospital size was entered in the first block, with CSR being entered in the second block. Lastly, the hospital controls associated with government, not-for-profit, and for-profit, along with their interaction terms with CSR being entered in the last step. Three models resulted, with only the control variable of number of hospital beds being significant in each. The beta coefficients, along with their associated t-values and $p$-values are shown in Table 7.

Model 1: EBT Margin $=\beta_{0}+\beta_{1} X_{1}$

Model 2: EBT Margin $=\beta_{0}+\beta_{1} X_{1}+\beta_{1} X_{1}$

Model 3: EBT Margin $=\beta_{0}+\beta_{1} X_{1}+\beta_{2} X_{2}+\beta_{3} X_{3}+\beta_{4} X_{4}+\beta_{5} X_{2} X_{3}+\beta_{6} X_{2} X_{4}$

$\begin{array}{ll}\text { Hospital Beds } & \mathrm{X}_{1} \\ \text { Charity Margin } & \mathrm{X}_{2}\end{array}$

First group, aka Control (not-for-profit): $\mathrm{X}_{3}=1, \mathrm{X}_{4}=0$

Second group, aka Control_2 (for-profit): $\mathrm{X}_{3}=0, \mathrm{X}_{4}=1$

Third group (government): $\quad \mathrm{X}_{3}=0, \mathrm{X}_{4}=0$

EBT Margin $=$ Earnings Before Taxes to Total Revenue: Dependent variable 
Table 7. Beta coefficients from stepwise regression analysis for EBT margin as the dependent variable

\begin{tabular}{|c|c|c|c|c|c|c|c|c|c|}
\hline \multirow[t]{2}{*}{ Variables } & \multicolumn{9}{|c|}{ Dependent Variable: Earnings Before Taxes to Total Revenue (EBT Margin) } \\
\hline & \multicolumn{3}{|c|}{ Model 1} & \multicolumn{3}{|c|}{ Model 2} & \multicolumn{3}{|c|}{ Model 3} \\
\hline \multirow{2}{*}{ Hospital Beds } & Coef & $t$ & $P$-value & Coef & $t$ & $P$-value & Coef & $t$ & $P$-value \\
\hline & 2.052 & 3.30 & $.001 * *$ & 2.051 & 3.30 & $.001 * *$ & 2.051 & 3.30 & $.001^{* *}$ \\
\hline Charity/Total Revenue & & & & .098 & .968 & .335 & .098 & .968 & .335 \\
\hline Control & & & & & & & -.084 & -1.08 & .284 \\
\hline Control_2 & & & & & & & .118 & 1.38 & .169 \\
\hline Control $\mathbf{x}$ Charity & & & & & & & .093 & .993 & .322 \\
\hline Control 2 x Charity & & & & & & & -.093 & -.921 & .358 \\
\hline $\mathbf{R}^{2} \mathbf{a d j}$ & & .056 & & & .056 & & & .056 & \\
\hline $\mathbf{F}$ & & 10.892 & & & 5.912 & & & 5.912 & \\
\hline $\mathrm{N}=167$ & & & & & & & & & \\
\hline$* \mathrm{p}<.05$ & & & & & & & & & \\
\hline$* * p<.01$ & & & & & & & & & \\
\hline
\end{tabular}

4.3.3 Additional Analysis: Test for Interaction with Net Profit Margin as the Dependent Variable

The following three models were assessed, this time with net profit margin (NPM) as the dependent variable. Once again, the only significant variable was the number of hospital beds, thus indicating the lack of an interaction effect between CSR and the three hospital controls. The beta coefficients, along with their associated t-values and p-values are shown in Table 8.

Model 1: NPM $=\beta_{0}+\beta_{1} X_{1}$

Model 2: $\mathrm{NPM}=\beta_{0}+\beta_{1} \mathrm{X}_{1}+\beta_{1} \mathrm{X}_{1}$

Model 3: NPM $=\beta_{0}+\beta_{1} X_{1}+\beta_{2} X_{2}+\beta_{3} X_{3}+\beta_{4} X_{4}+\beta_{5} X_{2} X_{3}+\beta_{6} X_{2} X_{4}$

Hospital Beds $\quad \mathrm{X}_{1}$

Charity Margin $\quad \mathrm{X}_{2}$

First group, aka Control (not-for-profit): $\mathrm{X}_{3}=1, \mathrm{X}_{4}=0$

Second group, aka Control_2 (for-profit): $\mathrm{X}_{3}=0, \mathrm{X}_{4}=1$

Third group (government): $\quad \mathrm{X}_{3}=0, \mathrm{X}_{4}=0$

NPM = Net Profit Margin: Dependent variable

Table 8. Beta coefficients from stepwise regression analysis for NPM as the dependent variable

\begin{tabular}{|c|c|c|c|c|c|c|c|c|c|}
\hline \multirow[t]{2}{*}{ Variables } & \multicolumn{9}{|c|}{ Dependent Variable: Net Profit Margin (NPM) } \\
\hline & \multicolumn{3}{|c|}{ Model 1} & \multicolumn{3}{|c|}{ Model 2} & \multicolumn{3}{|c|}{ Model 3} \\
\hline & Coef & $t$ & $P$-value & Coef & $t$ & $P$-value & Coef & $t$ & $P$-value \\
\hline Hospital Beds & 6.610 & 3.11 & $.002 * *$ & 6.610 & 3.11 & $.002 * *$ & 6.610 & 3.11 & $.002 * *$ \\
\hline Charity/Total Revenue & & & & -.011 & -.031 & .975 & -.011 & -.031 & .975 \\
\hline Control & & & & & & & -.070 & -.889 & .375 \\
\hline Control 2 & & & & & & & .107 & 1.25 & .213 \\
\hline Control $x$ Charity & & & & & & & .101 & 1.07 & .288 \\
\hline Control_2 x Charity & & & & & & & -.099 & -.977 & .330 \\
\hline $\mathbf{R}^{2} \mathbf{a d j}$ & & $5 \%$ & & & $4.4 \%$ & & & $4.4 \%$ & \\
\hline $\mathbf{F}$ & & 9.698 & & & 4.820 & & & 4.820 & \\
\hline $\begin{array}{l}\mathrm{N}=167 \\
*_{p}<.05 \\
* * p<.01\end{array}$ & & & & & & & & & \\
\hline
\end{tabular}




\section{Summary and Conclusions}

\section{1 Hospitals and the Level of Corporate Social Responsibility}

The results from this study suggest that for-profit hospitals do exhibit a reasonable level of corporate social responsibility. This is based upon the following:

1) A hospital's level of charity care is one key indicator of CSR (for a hospital).

2) For-profit hospitals in Florida contributed, on average, 1.9\% of their operating revenue to charity care.

3) The average operating profit margin for Florida for-profit hospitals was $5.4 \%$ of operating revenue. Given this average operating profit margin of $5.4 \%, 1.9 \%$ of operating revenue utilized for charity care would appear to be quite socially responsible.

Not-for-profit hospitals contributed a higher percentage of operating revenue (4.0\%) to charity care. A higher percentage would be expected, since:

1) The tax exemptions provided to not-for-profit hospitals are often justified by the community benefits they provide and these community benefits will likely include the provision of charity care.

2) Provision of charity care may be part of the hospital's mission.

3) Not-for-profit hospitals do have to make a "profit" to provide for future investments in the hospital. The average not-for-profit hospital in Florida had an operating profit margin of 2.6\%. The funds generated from these profits can be utilized directly for future investment in the hospital, since there are not stockholders to which dividends are paid. They can thus afford to contribute more to charity care than a for-profit hospital can.

Government hospitals provided the largest percentage of operating revenue $(5.8 \%)$ to charity care. This again can be expected, for the same reasons as those for not-for-profit hospitals. Additionally, government hospitals are likely to be provided with additional funding from local and/or state government, thus lowering the need to accumulate excess revenue for future investment and providing additional funds for charity care.

\subsection{Corporate Social Responsibility and Profitability in Hospitals}

Overall, the regression results indicated that there was no significant relationship between corporate social responsibility (as measured by charity care) and hospital profitability (as measured by operating profit margin, earnings before taxes margin, and net profit margin) in Florida hospitals. However, when considering only for-profit hospitals, a significant negative relationship between CSR and the profitability measure of OPM was found. The percentage of variability in operating profit margin explained was however only $3 \%$. The effect is thus so small that it is of little practical importance. For not-for-profit and government hospitals, no significant relationships were found between CSR and profitability.

This supports the idea that CSR does not necessarily affect the bottom line. While clearly the provision of charity care does result in a direct reduction of revenue, for the hospital industry (in Florida at least) this is apparently offset by other benefits that improve profitability. Provision of charity care by a hospital could result in benefits such as an improved hospital reputation and positive publicity in the community. This could result in attracting more paying patients and thus improve the hospital's financial performance. Another potential benefit could be in the attraction of better employees (including physicians and nurses) to the hospital which again should help to offset the cost of providing charity care.

As a whole, the results suggest that there is little or no downside to a hospital exhibiting corporate social responsibility (as indicated by the provision of charity care). It should be noted though that this has obvious limits. At some point the provision of charity care would necessarily result in negative financial performance. The mean level of charity care was $3.2 \%$, with a low of $0 \%$ and a high of $14.1 \%$. The assertion that there is little or no downside to a hospital's provision of charity care must thus be limited to a similar range for charity care.

The added value of this research may be associated with the use of both the normative and instrumental approaches of stakeholder theory. The results were examined in a normative fashion, in that the ideal standard or model of corporate social responsibility would include circumstances where hospitals of any type may provide some level of charitable care because it is the right thing to do. The instrumental aspect of stakeholder theory is illustrated as well in the benefits outlined that are beyond the direct impact on a hospital's bottom line such that actually providing charity care may directly cause positive events. 


\subsection{Limitations and Suggestions for Future Research}

As noted previously, this study was limited to hospitals located in the state of Florida. Environmental differences such as population demographics and governmental regulation may thus limit the study's generalizability. The study's generalizability is also limited to hospital organizations. Although the study does provide an illustration of the effects of corporate responsibility, the costs and benefits associated with corporate social responsibility in other types of organizations may vary significantly. Lastly, the provision of charity care is only one potential aspect of corporate social responsibility in hospitals. There are other aspects of CSR in hospitals that could be considered, including those related to environmental and employee policies.

Future research could expand the definition of corporate social responsibility to provide a more complete picture. In hospitals specifically, an exploration of how the affordable care act is affecting the provision of charity care in hospitals would also be of interest. Will hospitals no longer feel bound to provide as much charity care?

\section{Acknowledgements}

The authors thank Katie Sample (a graduate business student) for her efforts in coding the data for this paper.

\section{References}

59C-1.039 Comprehensive Medical Rehabilitation Inpatient Services. Florida Administrative Weekly, 1-5. Retrieved from https://www.flrules.org/

Alexander, J., Anderson, J., \& Lewis, B. (1985). Toward an empirical classification of hospitals in multihospital systems. Medical Care, 23, 913-932. http://dx.doi.org/10.1097/00005650-198507000-00007

Bowen, H. R., \& Johnson, F. E. (1953). Social responsibility of the businessman: Harper.

Carroll, A. B. (1979). A three-dimensional conceptual model of corporate performance. Academy of Management Review, 4(4), 497-505. http://dx.doi.org/10.5465/AMR.1979.4498296

Carroll, A. B., \& Shabana, K. M. (2010). The business case for corporate social responsibility: a review of concepts, research and practice. International Journal of Management Reviews, 12(1), 85-105. http://dx.doi.org/10.1111/j.1468-2370.2009.00275.x

Cheit, E. F. (1964). The business establishment: Wiley.

Davis, K. (1960). Can business afford to ignore social responsibilities? California Management Review, 2(3). http://dx.doi.org/10.2307/41166246

Donaldson, T., \& Preston, L. E. (1995). The stakeholder theory of the corporation: Concepts, evidence, and implications. Academy of Management Review, 20(1), 65-91. http://dx.doi.org/10.5465/AMR.1995.9503271992

Finkelstein, S. (1992). Power in top management teams: Dimensions, measurement and validation. Academy of Management Journal, 35(3), 505-538. http://dx.doi.org/10.2307/256485

Freeman, R. E. (1984). Strategic management: A stakeholder approach: Cambridge University Press.

Frooman, J. (1999). Stakeholder influence strategies. Academy of Management Review, 24(2), 191-205. http://dx.doi.org/10.5465/AMR.1999.1893928

Hill, C. W., \& Jones, T. M. (1992). Stakeholder-agency theory. Journal of Management Studies, 29(2), 131-154. http://dx.doi.org/10.1111/j.1467-6486.1992.tb00657.x

Kimberly, J., \& Evanisko, M. (1981). Organizational innovation: The influence of individual, organizational, and contextual factors on hospital adoption of technological and administrative innovations. Academy of Management Journal, 24(4), 689-713. http://dx.doi.org/10.2307/256170

Lynch, W. (2013). How Much Does Health Care Cost? More Than You Can - or Want - to Imagine. Systems Research for Better Health. from http://altarum.org/health-policy-blog/how-much-does-health-care-cost-more-than-you-can-or-want-to-imagine\# sthash.UGH6dLCJ.dpuf

Maignan, I., Ferrell, O. C., \& Hult, G. T. M. (1999). Corporate citizenship: cultural antecedents and business benefits. Journal of the Academy of Marketing Science, 27(4), 455-469. http://dx.doi.org/10.1177/0092070399274005

Marsteller, J. A., Bovbjerg, R. R., \& Nichols, L. M. (1998). Nonprofit conversion: theory, evidence, and state policy options. Health Services Research, 33(5 Pt 2), 1495-1535. 
McWilliams, A., \& Siegel, D. (2001). Corporate social responsibility: A theory of the firm perspective. Academy of Management Review, 26(1), 117-127. http://dx.doi.org/10.5465/AMR.2001.4011987

McWilliams, A., Siegel, D. S., \& Wright, P. M. (2006). Corporate social responsibility: Strategic implications*. Journal of Management Studies, 43(1), 1-18. http://dx.doi.org/10.1111/j.1467-6486.2006.00580.x

Meyer, A., \& Goes, J. (1988). Organizational assimilation of innovations: A multilevel contextual analysis. Academy of Management Journal, 31, 897-923. http://dx.doi.org/10.2307/256344

Munro, D. (2014). U.S. Annual Healthcare Spending Is A Stunning \$3.4 Trillion, Says Study. Pharma \& Healthcare, from

http://www.forbes.com/sites/danmunro/2014/11/17/new-deloitte-study-u-s-healthcare-spending-for-2012-was-o ver-3-4-trillion/

The New Health Care Delivery System - A Guide For Nurses. (2014). from http://www.afscme.org/news/publications/health-care/the-new-health-care-delivery-system-a-guide-for-nurses/ what-are-the-major-trends-affecting-health-care

Resnik, D. (2007). Responsibility for health: personal, social, and environmental. Journal of Medical Ethics, 33(8), 444-445. http://dx.doi.org/10.1136/jme.2006.017574

Solomon, R. C. (1985). It's good business. New York: Atheneum.

Tate, R. (1998). An Introduction to modeling outcomes in the behavioral and social sciences (2 ed.). Boston, MA: Pearson.

Tozzi, J. (2014). Why hospitals want patients to pay upfront. Bloomberg Businessweek. Retrieved from http://www.businessweek.com/articles/2014-09-25/why-hospitals-want-patients-to-pay-upfront

Winn, M. I., MacDonald, P., \& Zietsma, C. (2008). Managing industry reputation: The dynamic tension between collective and competitive reputation management strategies. Corporate Reputation Review, 11(1), 35-55. http://dx.doi.org/10.1057/crr.2008.4

Zajac, E., \& Shortell, S. (1989). Changing generic strategies: Likelihood, direction and performance implications. Strategic Management Journal, 10, 413-430. http://dx.doi.org/10.1002/smj.4250100503 